
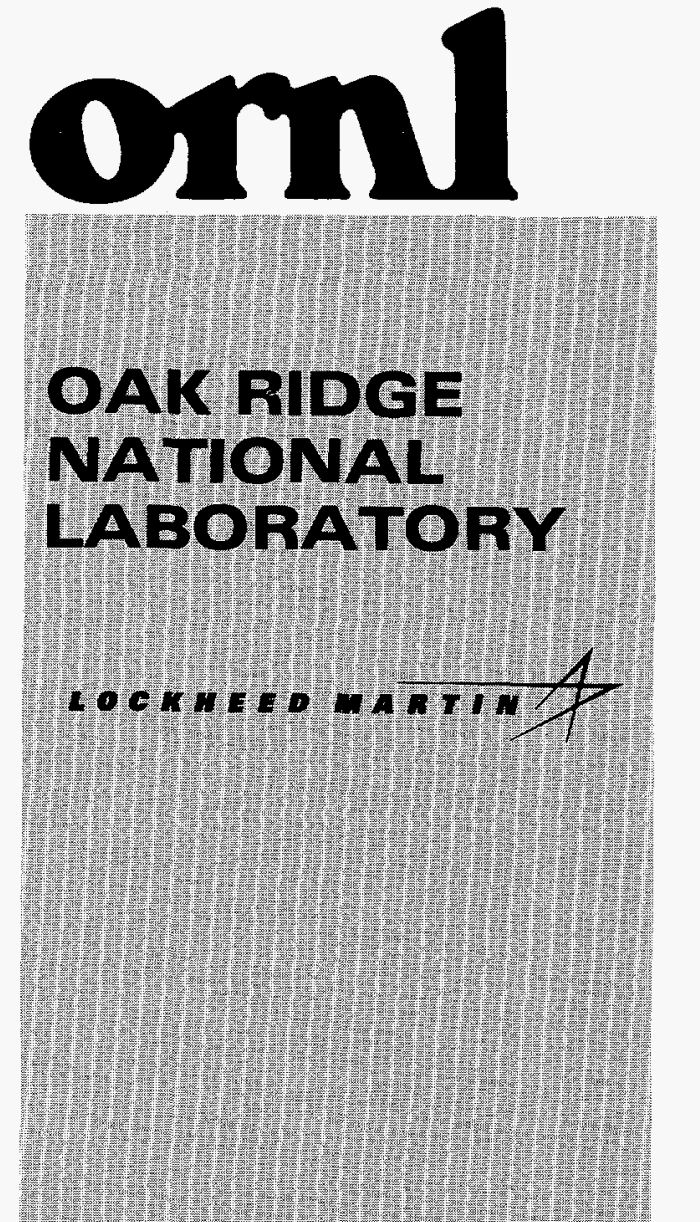

(1) (t) 1) (1)

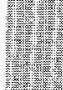

1.t.
RECEIVED

Alli 071997

OSTI

Results of the Independent Radiological Verification Survey at the Former Chapman Valve Manufacturing Company, Indian Orchard, Massachusetts (CIO001V)

R. E. Rodriguez

C. A. Johnson

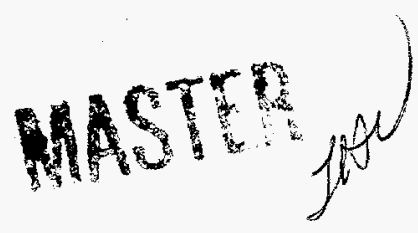

DISTRIBUTION OF THIS DOCUMENI IS UNLAMTERA 
This report has been reproduced directly from the best available copy.

Available to DOE and DOE contractors from the Office of Scientific and Technical Information, P. O. Box 62, Oak Ridge, TN 37831; prices available from i423) $576-8401$, FTS 626-8401.

Available to the public from the National Technical Information Service, U.S. Department of Commerce, 5285 Port Royal Road. Springfield. VA, 22161.

This report was prepared as an account of work sponsored by an agency of the United States Government. Neither the United States Government no: any agency thereof, nor any of their employees, makes any warranty, express or implied, or assumes any legal liability or responsibility for the accuracy. completeness, or usefulness of any information, ap|jaratus, product, or process disclosed, or represents that its use would not infringe privately owned rights. Reference herein to any specific commercial product, process, or service by trade name. trademark, manıfacturer, or otherwise, does not necessarily constitute or imply its endorsement, recommendation, or favoring by the United States Government or any agency thereof. The views and opinions of authors expressied herein do not necessarily state or reflect those of the United States Government of any agency thereof. 


\section{DISCLAIMER}

Portions of this document may be illegible in electronic image products. Images are produced from the best available original document. 
LIFE SCIENCES DIVISION

Environmental Restoration and Waste Management Non-Defense Programs

(Activity No. EX 202001 0; ADS1310AA)

\title{
Results of the Independent Radiological Verification Survey at the Former Chapman Valve Manufacturing Company, Indian Orchard, Massachusetts (CIO001V)
}

\author{
R. E. Rodriguez and C. A. Johnson
}

Date issued - May 1997

Investigation Team

R. D. Foley-Measurement Applications and Development Manager

M. E. Murray-FUSRAP Project Director

R. E. Rodriguez-Field Survey Team Leader

Survey Team Members

R. C. Gosslee V.P. Patania

R. E. Rodriguez

Work performed by the

Measurement Applications and Development Group

Prepared by the

OAK RIDGE NATIONAL LABORATORY

Oak Ridge, Tennessee 37831-6285

managed by

LOCKHEED MARTIN ENERGY RESEARCH CORP.

for the

U. S. DEPARTMENT OF ENERGY

under contract DE-AC05-960R22464 


\section{CONTENTS}

LIST OF FIGURES ….................................................. v

LIST OF TABLES ...................................................... vii

ACKNOWLEDGMENTS............................................... ix

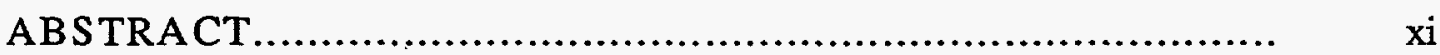

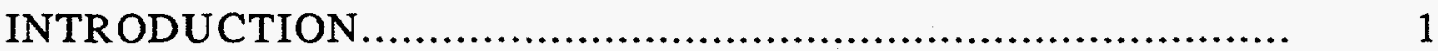

VERIFICATION PROCEDURES........................................... 2

OBJECTIVES ................................................... 2

SURVEY METHODS ............................................. 2

VERIFICATION SURVEY AND ANALYSIS................................... 3

DIRECT AND REMOVABLE RADIOACTIVITY LEVELS............... 3

SOIL SAMPLES.......................................................

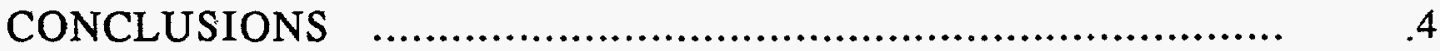

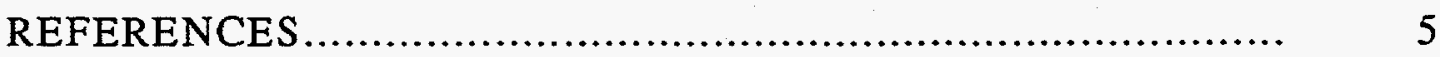





\section{LIST OF FIGURES}

1 Location of Building 23 at the site of the former Chapman Valve

Manufacturing Company, Indian Orchard Massachusetts.

2 Building 23 at the site of the former Chapman Valve Manufacturing

Company, Indian Orchard, Massachusetts.

3 Locations of directly measured beta-gamma activity levels (dpm/100 $\mathrm{cm}^{2}$ ) and smears collected on Truss \# 1 in Building 23 at the site of the former Chapman Valve facility

4 Locations of directly measured beta-gamma activity levels $\left(\mathrm{dpm} / 100 \mathrm{~cm}^{2}\right)$ and smears collected on Truss \# 2 in Building 23 at the site of the former Chapman Valve facility, Indian Orchard, Massachusetts.

5 Locations of directly measured beta-gamma activity levels (dpm/100 $\left.\mathrm{cm}^{2}\right)$ and smears collected on Truss \# 3 in Building 23 at the site of the former Chapman Valve facility, Indian Orchard, Massachusetts.

6 Locations of directly measured beta-gamma activity levels (dpm/100 $\mathrm{cm}^{2}$ ) and smears collected on Truss \# 4 in Building 23 at the site of the former Chapman Valve facility, Indian Orchard, Massachusetts.

7 Locations of directly measured beta-gamma activity levels $(\mathrm{dpm} / 100 \mathrm{~cm} 2)$ and smears collected on Truss \# 5 in Building 23 at the site of the former Chapman Valve facility, Indian Orchard, Massachusetts.

8 Locations of directly measured beta-gamma activity levels $\left(\mathrm{dpm} / 100 \mathrm{~cm}^{2}\right)$ and smears collected on Truss \# 6 in Building 23 at the site of the former Chapman Valve facility, Indian Orchard, Massachusetts.

9 Locations of directly measured beta-gamma activity levels (dpm/100 $\left.\mathrm{cm}^{2}\right)$ and smears collected on Truss \# 7 in Building 23 at the site of the former Chapman Valve facility, Indian Orchard, Massachusetts.

10 Locations of soil samples collected at the site of the former Chapman Valve facility, Indian Orchard, Massachusetts. 


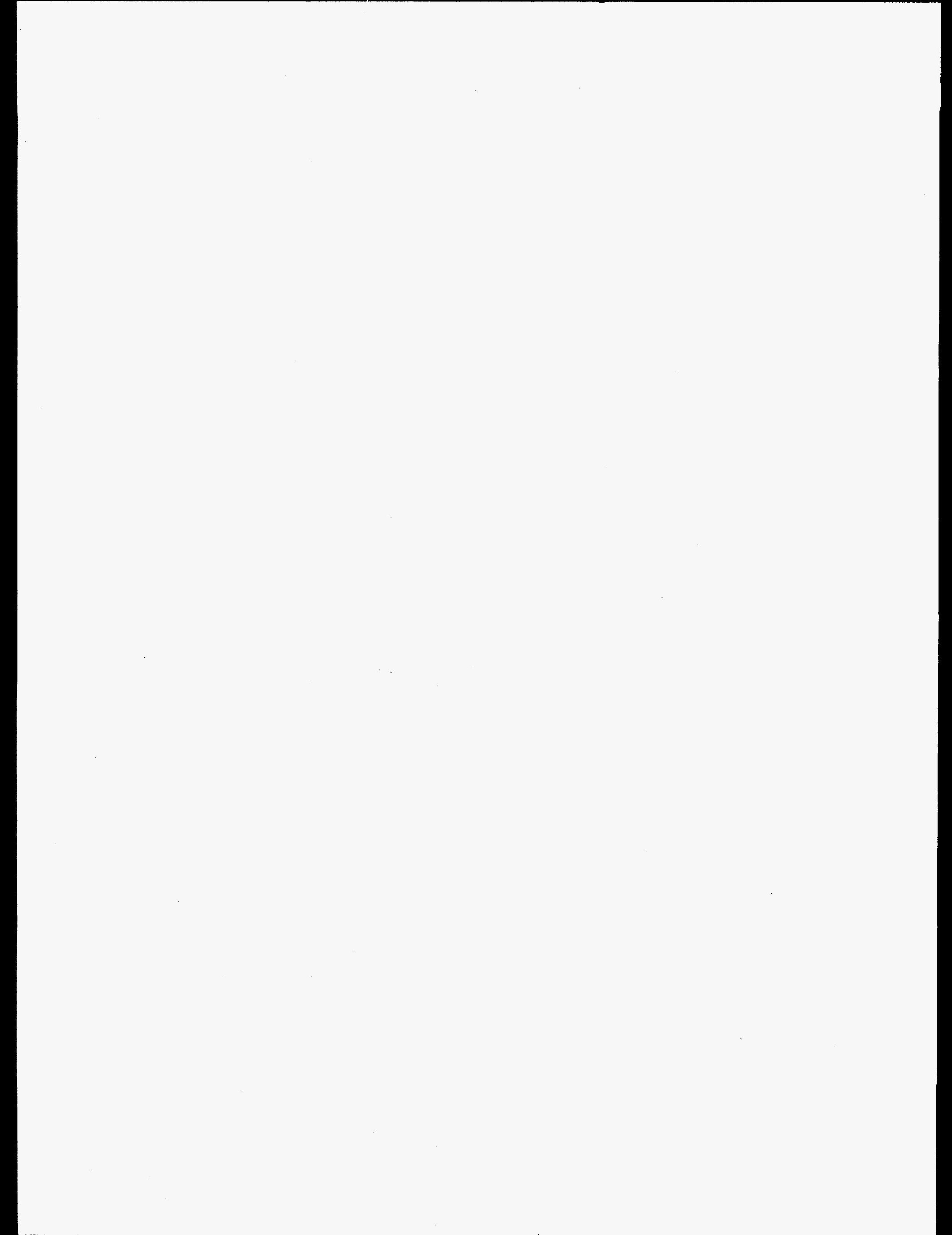




\section{LIST OF TABLES}

1 Applicable guidelines for protection against radiation..........................

2 Background radiation levels and concentrations of selected radionuclides in soil in the Beverly, Massachusetts, area

3 Direct and transferable beta-gamma and alpha measurements on overhead trusses in Building 23 for the verification of the former Chapman Valve Manufacturing Company facility.............................................

4 Concentrations of radionuclides in soil at the former Chapman Valve Manufacturing Company, Indian Orchard, Massachusetts (CIO001V)...... 



\section{ACKNOWLEDGMENTS}

This project was sponsored by the Office of Environmental Restoration, U. S. Department of Energy, under contracts DE-AC05-84OR21400 with Martin Marietta Energy Systems, Inc., and DE-AC05-960R22464 with Lockheed Martin Energy Research Corp. The authors wish to acknowledge the contributions of D. A. Roberts, D. A. Rose, and R. C. Phillips of the Measurement Applications and Development Group for participation in the sample preparation and analyses, graphics, and reporting of data for this survey. The surveying assistance of R. C. Gosslee and V. P. Patania is also gratefully acknowledged. 



\begin{abstract}
The Chapman Valve Manufacturing Company in Indian Orchard, Massachusetts was one of many companies performing work during the 1940s associated with the development of nuclear energy for defense-related projects for the Manhattan Engineer District (MED) and the Atomic Energy Commission (AEC). In 1947 Chapman set aside approximately one-third of Building 23 at the Chapman site for the machining of uranium rods. The "set aside" portion of the building measured $\sim 200$ by $60 \mathrm{ft}$ and was separated from the remainder of the building by a floor-toceiling wooden partition.
\end{abstract}

In 1991, a radiological survey was conducted at the former Chapman Valve Manufacturing Company by members of the Measurement Applications and Development (MAD) Group of the Oak Ridge National Laboratory (ORNL) at the request of the U.S. Department of Energy (DOE). The survey report, published in 1992, concluded that survey results indicated 238U contamination in excess of the DOE criteria for surface contamination, and some $235 \mathrm{U}$ residues in the west end of the building.

Decontamination of the facility to supplemental guidelines, derived by a hazard assessment based on appropriate scenarios for this building, was conducted by subcontractor personnel in 1995 under the direction of Bechtel National Incorporated (BNI), the project management contractor for FUSRAP. The independent radiological verification survey detailed in this report was performed in July and August 1995 under the FUSRAP program by members of ORNL at the request of DOE.

The radiological verification survey of the west end of the building included gamma, alpha, and beta-gamma scans for fixed contamination, smear sampling for transferable contamination, and radionuclide analysis of soil samples taken from outside the building and from excavations in the concrete floor inside the building.

Additionally, DOE has committed to conduct an additional radiological survey after demolition of the building by the propety owner.

Based on the results of the remedial action and verification data in this report, all radiological measurements fall below the limits prescribed by DOE radiological guidelines established for this site. 


\section{Results of the Independent Radiological Verification Survey at the Former Chapman Valve Manufacturing Company, Indian Orchard, Massachusetts (CIO001V)*}

\section{INTRODUCTION}

The Chapman Valve Manufacturing Company in Indian Orchard, Massachusetts, was one of many companies performing work during the 1940s associated with the development of nuclear energy for defense-related projects for the Manhattan Engineer District (MED) and the Atomic Energy Commission (AEC). Operations conducted under government contract at such sites included the procurement, storage, and processing of uranium oxides, salts, and metals, and the subsequent machining of these products. As a result of activities involving these materials, equipment, buildings, and land at some of the sites became radiologically contaminated with small amounts of the material resulting in low levels of contamination on the properties. The Formerly Utilized Sites Remedial Action Program (FUSRAP) was established by DOE in 1974 to assist in the assessment and cleanup activities at these sites. 1

In 1947 Chapman set aside approximately one-third of Building 23 at the Chapman site, 203 Hampshire Street, Indian Orchard, Massachusetts, for the machining of uranium rods for Brookhaven Laboratory. The "set aside" portion of the building measured $~ 200$ by $60 \mathrm{ft}$ and was separated from the remainder of the building by a floor-to-ceiling wooden partition, which has since been removed. Chapman became part of the Crane Company in 1959. Building 23 has been vacant since Crane discontinued all manufacturing at Indian Orchard early in 1987.2

In 1991, a radiological survey was conducted at the former Chapman Valve Manufacturing company by members of the Measurement Applications and Development (MAD) Group of the Oak Ridge National Laboratory (ORNL) at the request of the U. S. Department of Energy (DOE). The survey and sampling at this site covered selected areas outdoors and accessible areas inside Building 23. Survey emphasis was on interior floors, walls and overhead beams. The survey report, published in 1992, concluded that survey results indicated $238 \mathrm{U}$ contamination in excess of the DOE criteria for surface contamination, and some $235 \mathrm{U}$ residues in the west end of the building. 3

Decontamination of the facility to supplemental guidelines, derived by a hazard assessment based on appropriate scenarios for this building, was conducted by subcontractor personnel in 1995 under the direction of Bechtel National Incorporated

${ }^{*}$ The survey was performed by members of the Measurement Applications and Development Group of the former Health Sciences Research Division (now the Life Sciences Division) of Oak Ridge National Laboratory under DOE contract DE-AC05-960R22464. 
(BNI), the project managernent contractor for FUSRAP. Thermo NUtech was the radiological support subcontractor.

The independent radiological verification survey detailed in this report was performed in July and August 1995 under the FUSRAP program by members of ORNL at the request of DOE. The policy to assign an independent verification contractor ensures the effectiveness of remedial actions performed within FUSRAP and confirms the site's compliance with DOE guidelines.

Figure 1 is a drawing of the former Chapman Valve Manufacturing Company property showing the location of Building 23 .

\section{VERIFICATION PROCEDURES}

\section{OBJECTIVES}

The objective of the verification activities was to confirm (1) that available documentation adequately and accurately describes the post-remedial condition of the facility that is to be verified, and (2) that the remedial action reduced contamination levels to within authorized limits. Applicable DOE residual radioactivity guidelines for protection of the general public are summarized in Table 1.

\section{SURVEY METHODS}

Survey methods followed guidelines for a generic site as outlined in References 4 and 5. Figures 2-10 are diagrams of the building indicating locations of scans, smears, and soil samples. The building has been divided into a series of survey blocks, with the east-west support columns and overhead beams numbered 1 to 31 , and the north-south columns labeled AA, A, B, and C (Fig. 2). Instrument calibrations were verified and background checked before each survey session.

Residual uranium was concentrated in the west end of the building, specifically blocks A1 through A7. The radiological verification survey of the west end of the building included: (1) a gamma scan at the surface of floors, using sodium iodide (NaI) gamma scintillation detectors; (2) beta-gamma scans of the floors and overhead structures with "pancake" GM detectors, and limited alpha scans on overhead structures with $\mathrm{ZnS}$ scintillation detectors; (3) a comprehensive scan of the floor surface for alpha-betagamma activity, using large area gas flow proportional detectors; (4) smear sampling at selected locations; and (5) radionuclide analysis of soil samples taken from outside the building and from core holes drilled through the concrete floor inside the building. 


\section{VERIFICATION SURVEY AND ANALYSIS}

Current guidelines for sites included within FUSRAP are summarized in Table 1. Typical background radiation levels for the Massachusetts area are presented in Table 2. These data are provided for comparison with the survey results presented in this section. Gamma measurements presented in this report are gross readings; background radiation levels have not been subtracted. Similarly, background concentrations have not been subtracted from radionuclide concentrations in soil.

Beta-gamma contamination levels were recorded in gross counts per minute (cpm), background adjusted and converted to disintegrations per minute $(\mathrm{dpm} / 100 \mathrm{~cm} 2)$ using standard geometry factors for beta-gamma pancake probe/Bicron ratemeter combination. Transferable radioactivity levels (smears) are reported as net counts with background subtracted.

\section{DIRECT AND REMOVABLE RADIOACTIVITY LEVELS}

Gamma exposure rates, taken at the initial survey, ranged from 5 to $11 \mu \mathrm{R} / \mathrm{h}$ at $1 \mathrm{~m}$ above the floor in grid blocks A1-A30 (see Fig. 2), while surface exposure rates ranged from 5 to $13 \mu \mathrm{R} / \mathrm{h}$. These values are comparable to the typical average background levels for the area (6 to $9 \mu \mathrm{R} / \mathrm{h}$, Table 2). Gamma levels at accessible floor and wall surfaces were higher on contact with bricks, concrete, and other materials that contain naturally occurring radioactivity.

Direct beta-gamma activity levels were measured on the overhead crane and at 81 locations on seven roof-support trusses (beams) in the west end of the building, where contamination was found in the first survey. The eighth truss was not included in the verification survey; after review of the post remedial survey data for truss no. 8 it was determined unnecessary. Some activity above guidelines was found on the crane during the initial survey by the verification team but was remediated and again surveyed and verified below guidelines. Beta-gamma activity measured on the trusses ranged from 400 to $60,000 \mathrm{dpm} / 100 \mathrm{~cm}^{2}$. When averaged over the first 8 trusses, these measurements meet the supplemental guidelines established for this site (i.e., an average surface level of not more than $15,000 \mathrm{dpm} / 100 \mathrm{~cm}^{2}$ of uranium activity for the first eight trusses). 6 Results are given in Table 3.

Direct alpha activity was measured on the west beams and in spots on the floors underneath the beams. None of the measurements were above guidelines. A comprehensive beta-gamma scan of the floors under these beams showed no beta-gamma measurements above guidelines. The building is scheduled for demolition by the owner.

Smears were collected at selected locations throughout the area surveyed to ensure that remedial efforts left no residual transferable radioactivity above established guidelines. Results from smear analyses indicate no removable beta-gamma activity 
above guidelines and the instrument-specific minimum detectable activity (MDA)* All alpha measurements were below guidelines (Table 1 ) for both fixed and transferable alpha activity.

\section{SOIL SAMPLES}

Systematic surface $(0-6$ in, or $0-15 \mathrm{~cm})$ soil samples were taken outdoors as well as indoors under the concrete floor where excavations had been dug by the remedial action contractor to remove the drainlines. Sample locations are shown on Fig. 3.

All samples were analyzed to determine the concentrations of $238 \mathrm{U}, 235 \mathrm{U}, 226 \mathrm{Ra}$, and 232Th. Results of the radionuclide analysis are shown in Table 4. Concentrations of 235U and $238 \mathrm{U}$ ranged from $<0.05$ to $0.46 \mathrm{pCi} / \mathrm{g}$, and 0.71 to $14 \mathrm{pCi} / \mathrm{g}$, respectively. The site specific guidelines for $238 \mathrm{U}$ concentrations of 35 to $40 \mathrm{pCi} / \mathrm{g}$ have been applied at other FUSRAP sites (Table 1). Concentrations for ${ }^{232} \mathrm{Th}$, and $226 \mathrm{Ra}$ in surface soil ranged from 0.27 to $0.43 \mathrm{pCi} / \mathrm{g}$ and from 0.43 to $0.65 \mathrm{pCi} / \mathrm{g}$, respectively. All these values are comparable to background levels in the area, and well below DOE guidelines.

\section{CONCLUSIONS}

Prior to remedial efforts, uranium residuals exceeded current DOE surface contamination guidelines in the west quadrant of Building 23. With the exception of the overhead crane, the rest of the building had been found to meet guidelines as reported in ORNL/RASA-92/1. The building will be demolished at a future date, when further verification of the site will be performed.

All known radioactivity at the site has been addressed during the remedial action, either by cleanup or by evaluation for Supplemental Standards. In addition, DOE has committed to the property owner and to the community to conduct an additional radiological survey after demolition of the building by the property owner. This will provide the property owner and community with additional confidence that the property does not contain residual uranium at levels that would affect health or safety of future site occupants.

Decontamination of the facility was performed by subcontractors under the direction of BNI. Initially, spotty contamination on the crane was identified by the ORNL verification team during the remediation efforts; however, these residuals were removed

* The MDA for transferable alpha and beta activity is 9 and $140 \mathrm{dpm} / 100 \mathrm{~cm}^{2}$, respectively. The critical detection level $\left(\mathrm{L}_{\mathrm{c}}\right)$ for transferable alpha and beta activity is 3 and 85 $\mathrm{dpm} / 100 \mathrm{~cm}^{2}$, respectively.

The MDA for direct alpha and beta measurements is $60 \mathrm{dpm} / 100 \mathrm{~cm}^{2}$ and $970 \mathrm{dpm} / 100 \mathrm{~cm}^{2}$, respectively. The $L_{c}$ for direct alpha and beta measurements is 20 and $440 \mathrm{dpm} / 100 \mathrm{~cm}^{2}$, respectively. 
and the areas resurveyed by Thermo NUtech personnel, followed by another radiological verification effort by the ORNL team.

Results of this independent radiological verification survey of Building 23 at the former Chapman Valve Manufacturing Company, Indian Orchard, Massachusetts confirm that residual uranium contamination in the west end of the building has been remediated to levels meeting the supplemental DOE guidelines for this site. The results of the direct scans and the removable smear analyses showed that all direct and transferable activity on the overhead beams and crane was below applicable guidelines. The results of soil radionuclide analyses indicate that all soil concentration measurements are below the limits prescribed by DOE radiological guidelines.

Based on the results of the remedial action and verification data in this report, all radiological measurements fall below the limits prescribed by DOE radiological guidelines established for this site.

\section{REFERENCES}

1. U. S. Department of Energy, A Background Report for the Formerly Utilized Manhattan Engineer District/Atomic Energy Commission Sites Program, DOE/EV-0097, September 1980.

2. T. J. Ungerland, Associate General Council, Crane Company, New York, NY, letter (with attachments) to J. J. Fiore, U.S. Department of Energy, Washington, DC, December 1987.

3. R. D. Foley, M. S. Uziel, Results of the Radiological Survey at the Former Chapman Valve Manufacturing Company, Indian Orchard, Massachusetts (CIO001), ORNL/RASA-92/1, Martin Marietta Energy Systems, Inc., Oak Ridge Natl. Lab., July 1992.

4. T. E. Myrick, B. A. Berven, W. D. Cottrell, W. A. Goldsmith, and F. F. Haywood, Procedures Manual for the ORNL Radiological Survey Activities (RASA) Program, ORNL/TM-8600, Martin Marietta Energy Systems, Inc., Oak Ridge Natl. Lab., April 1987.

5. Oak Ridge National Laboratory, Health Sciences Research Division, Measurement Applications and Development Group Guidelines, ORNL-6782, Martin Marietta Energy Systems, Inc., January 1995.

6. J. W. Wagoner II, Director, Division of Off-Site Programs, Office of Eastern Area Programs, Office of Environmental Restoration, U. S. DOE, memorandum to L. K. Price, Director, Former Sites Restoration Division, Oak Ridge Field Office, U. S. DOE, July 27, 1995. 


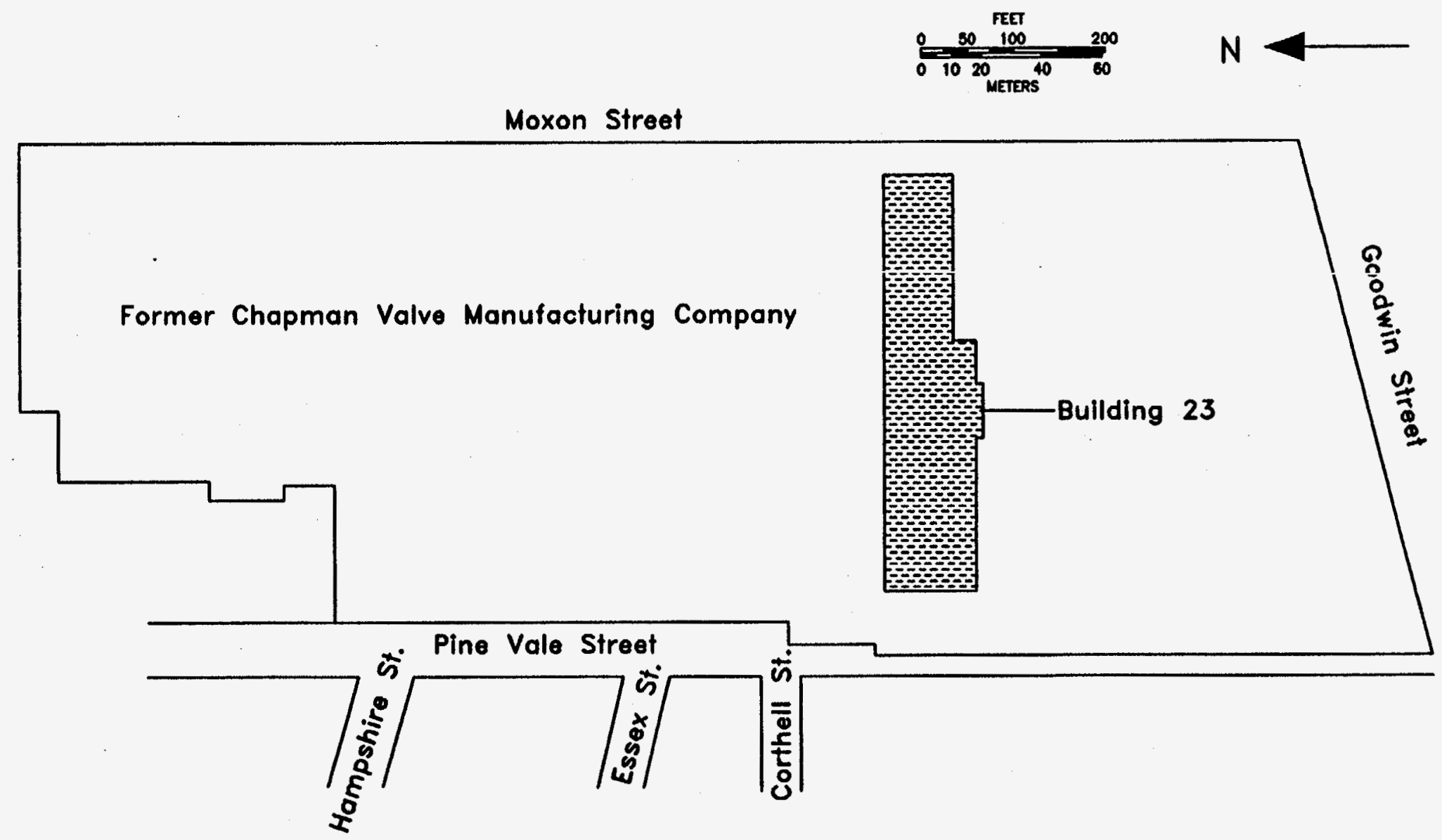

क

Fig. 1. Location of Building 23 at the site of the former Chapman Valve Manufacturing Company, Indian Orchard, Massachusetts. 


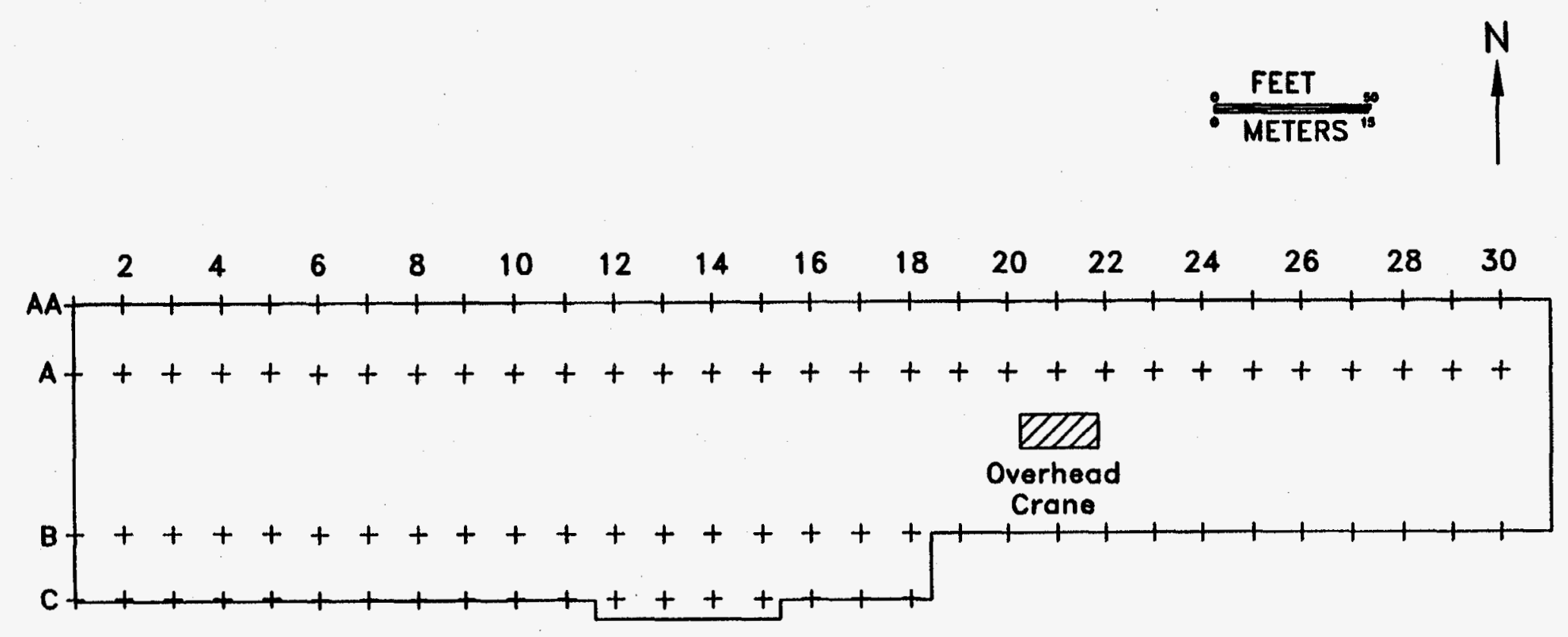

Fig. 2. Building 23 at the site of the former Chapman Valve Manufacturing Company, Indian Orchard, Massachusetts. Overhead roof support trusses are numbered 1 to 31 and columns are labeled AA to $C$. The mobile overhead crane is shown in the eastern half of the building. 


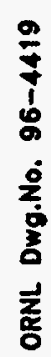

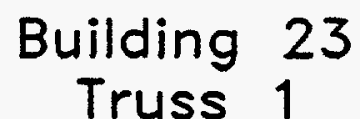

$V T$ - Location of smears

- Numbered locations of direct scans

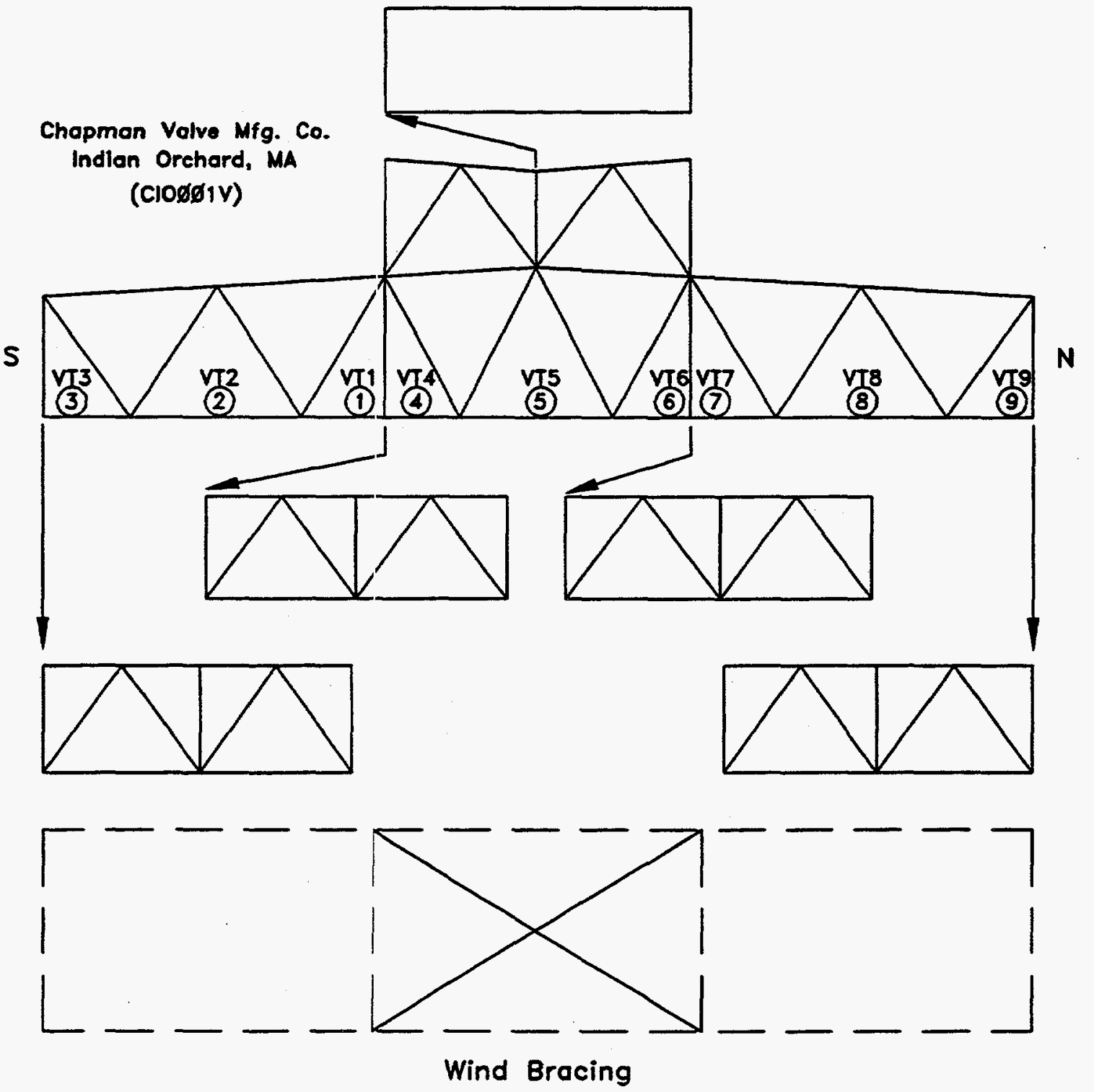

Fig. 3. Locations of directly measured beta-gamma activity levels (dpm/100 cm ${ }^{2}$ ) and smears collected on Truss \#1 in Building 23 at the site of the former Chapman Valve facility. Results of alpha and beta-gamma scans on all trusses are shown in Table 3. 


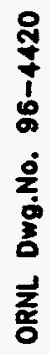

\section{Building 23 \\ Truss 2}
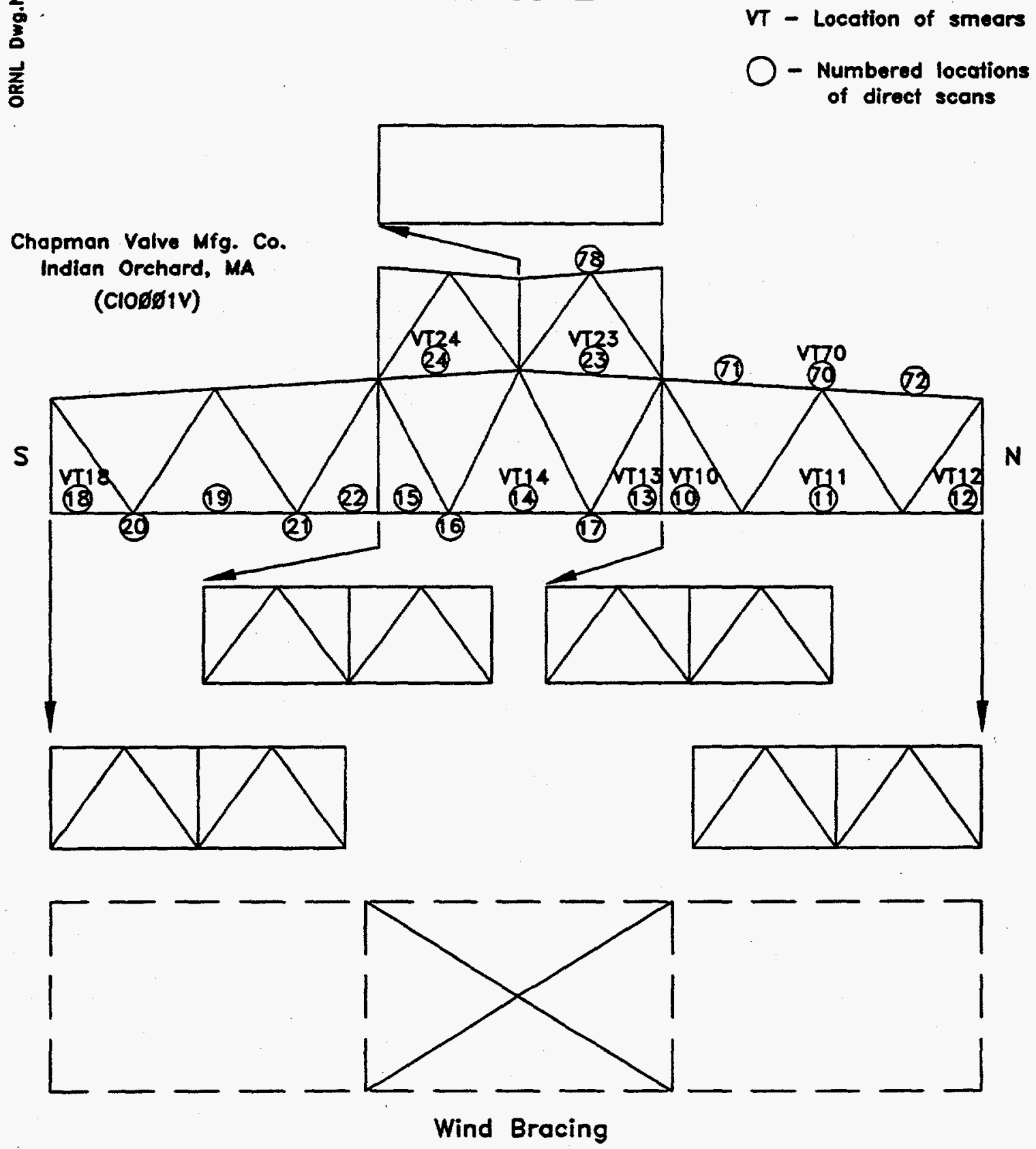

Fig. 4. Locations of directly measured beta-gamma activity levels $\left(\mathrm{dpm} / 100 \mathrm{~cm}^{2}\right.$ ) and smears collected on Truss \#2 in Building 23 of the site of the former Chapman Valve facility, Indian Orchard, Massachusetts. 


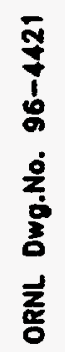

Building 23

Truss 3

$$
\begin{gathered}
V T \text { - Location of smears } \\
O \text { - Numbered locations } \\
\text { of direct scans }
\end{gathered}
$$

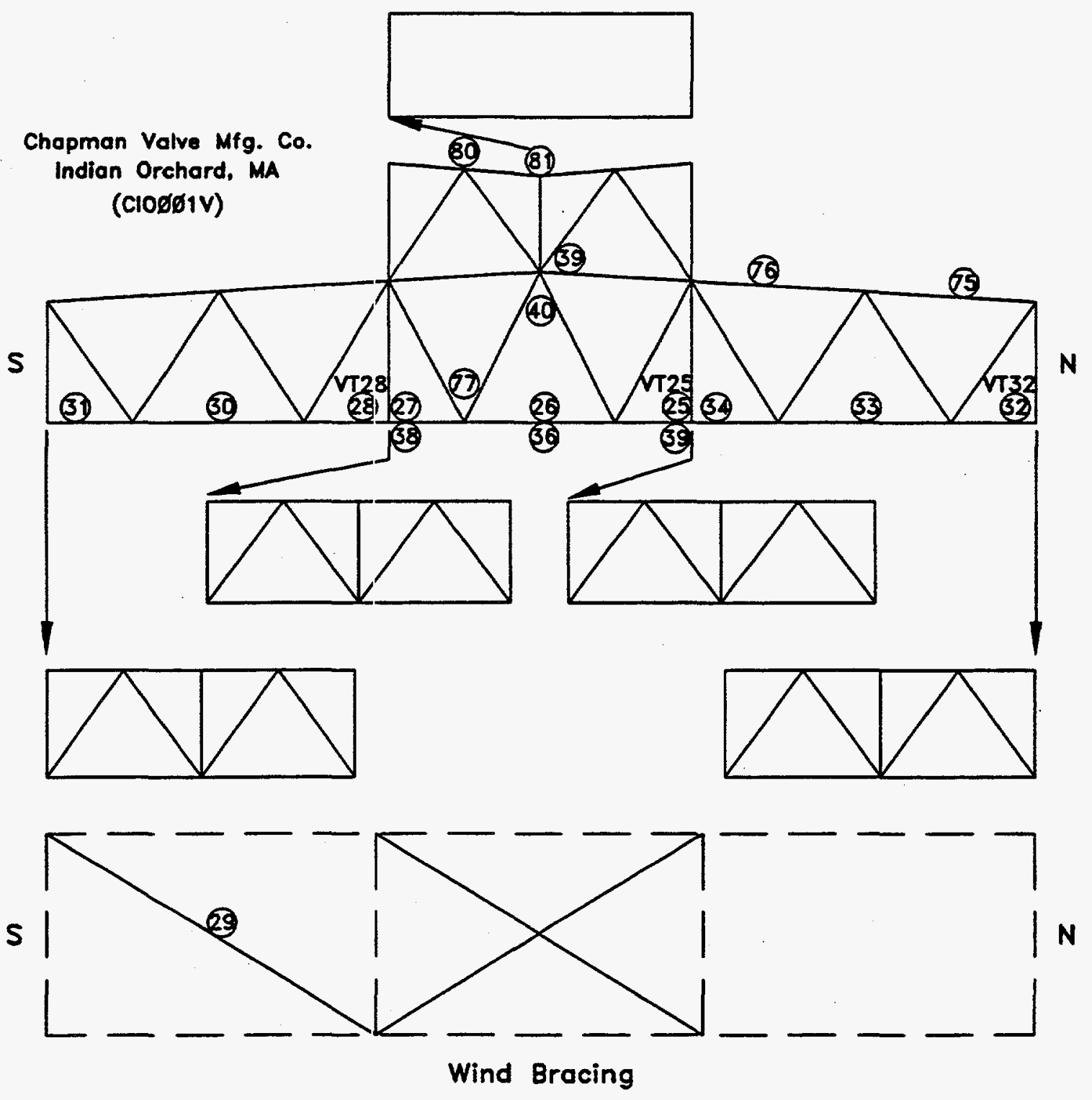

Fig. 5. Locations of directly measured beta-gamma activity levels (dpm/100 $\mathrm{cm}^{2}$ ) and smears collected on Truss \#3 in Building 23 at the site of the former Chapman Valve facility, Indian Orchard, Massachusetts. 


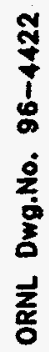
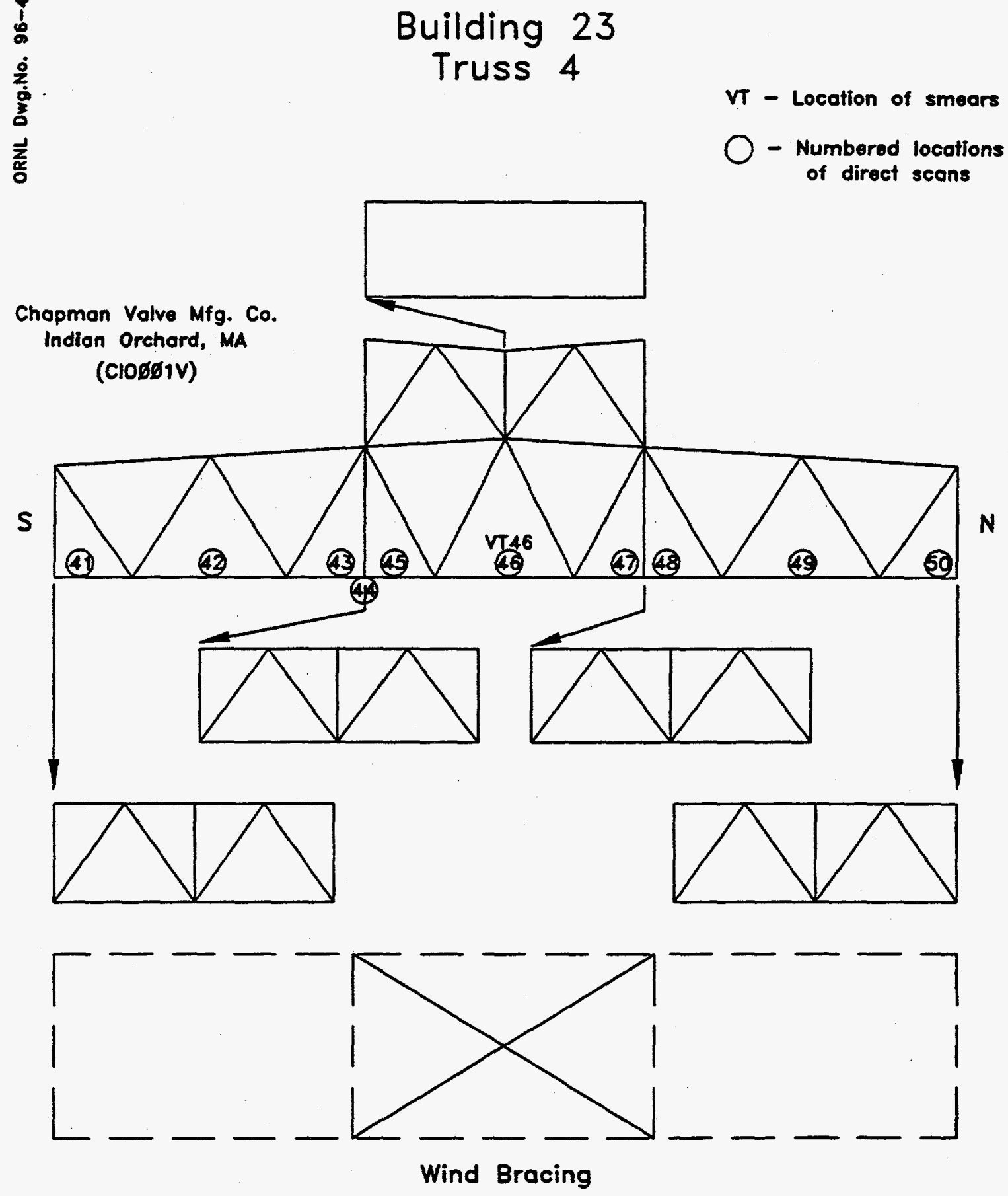

Fig. 6. Locations of directly measured beta-gamma activity levels (dpm/100 $\mathrm{cm}^{2}$ ) and smears collected on Truss \#4 in Building 23 at the site of the former Chapman Valve facility, Indian Orchard, Massachusetts. 


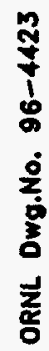
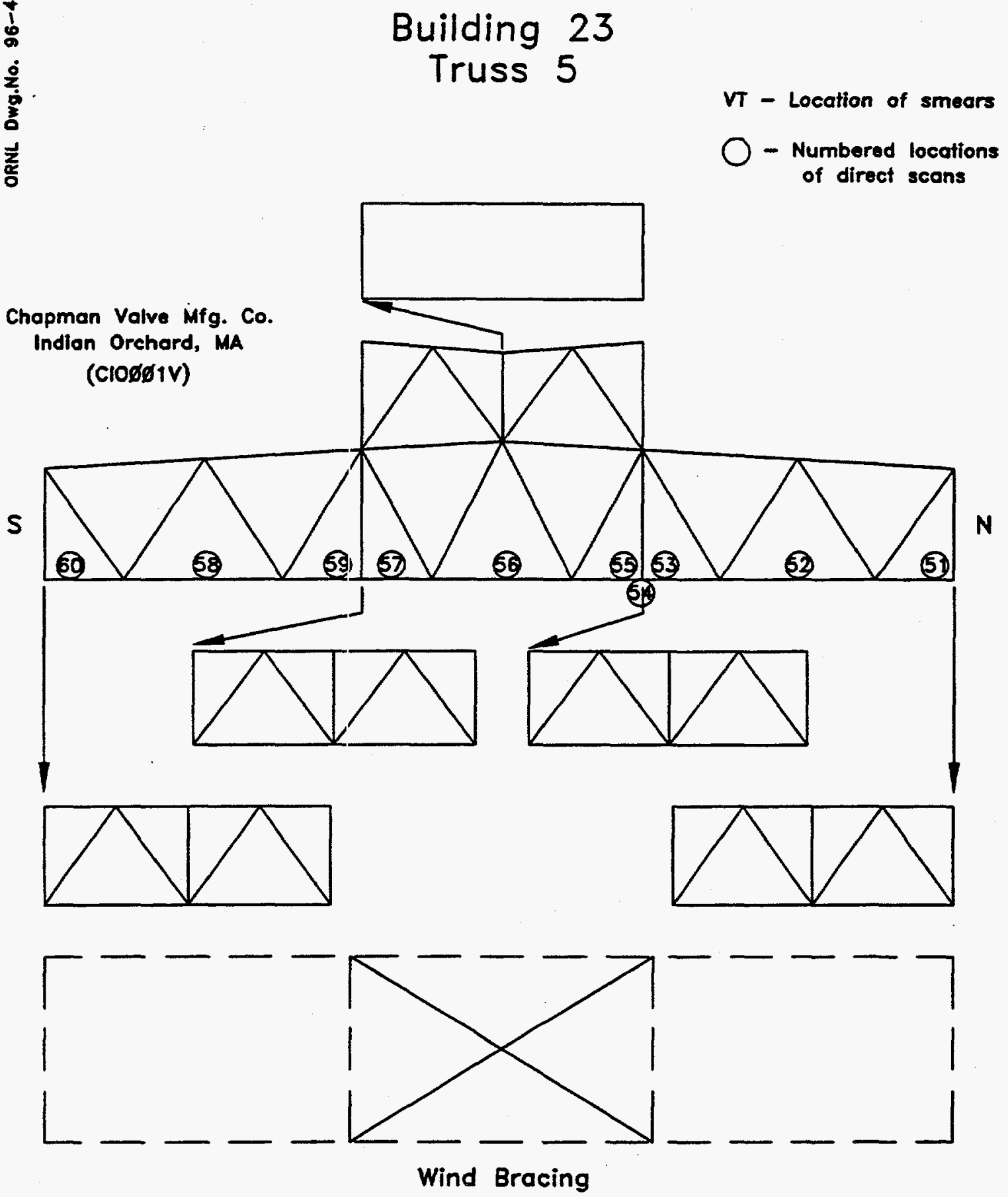

Fig. 7. Locations af directly measured beta-gamma activity levels (dpm/100 $\mathrm{cm}^{2}$ ) and smears collected on Truss \#5 in Building 23 at the site of the former Chapınan Valve facility, Indian Orchard, Massachusetts. 


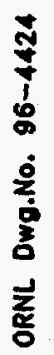

Building 23

Truss 6
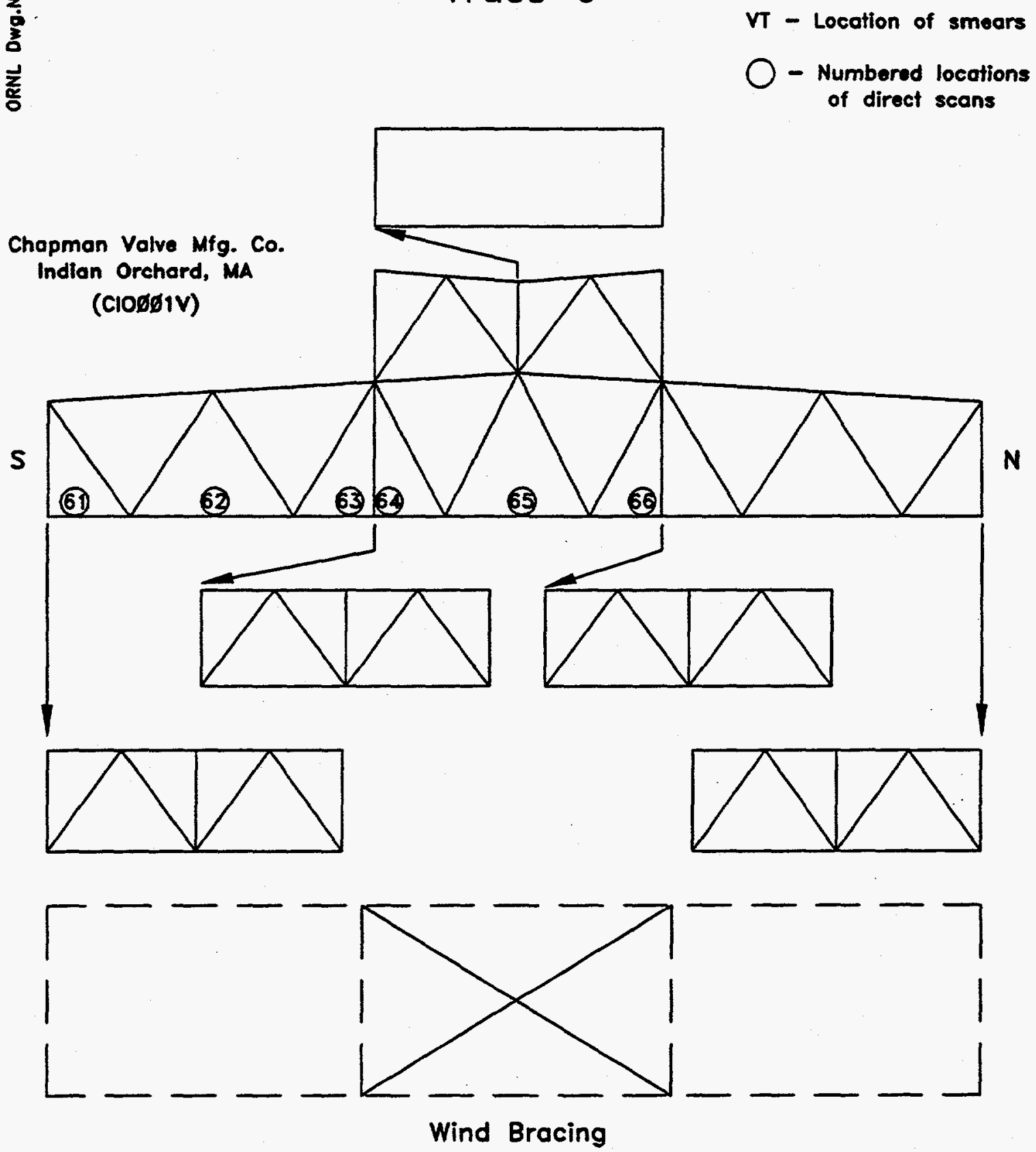

Fig. 8. Locations of directly measured beta-gammo activity levels (dpm/100 $\mathrm{cm}^{2}$ ) and smears collected on Truss \#6 in Building 23 at the site of the former Chapman Valve facility, Indian Orchard, Mossochusetts. 


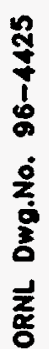

\section{Building 23 \\ Truss 7}

$$
\begin{gathered}
v T \text { - Location of smears } \\
O \text { - Numbered locations } \\
\text { of direct scans }
\end{gathered}
$$

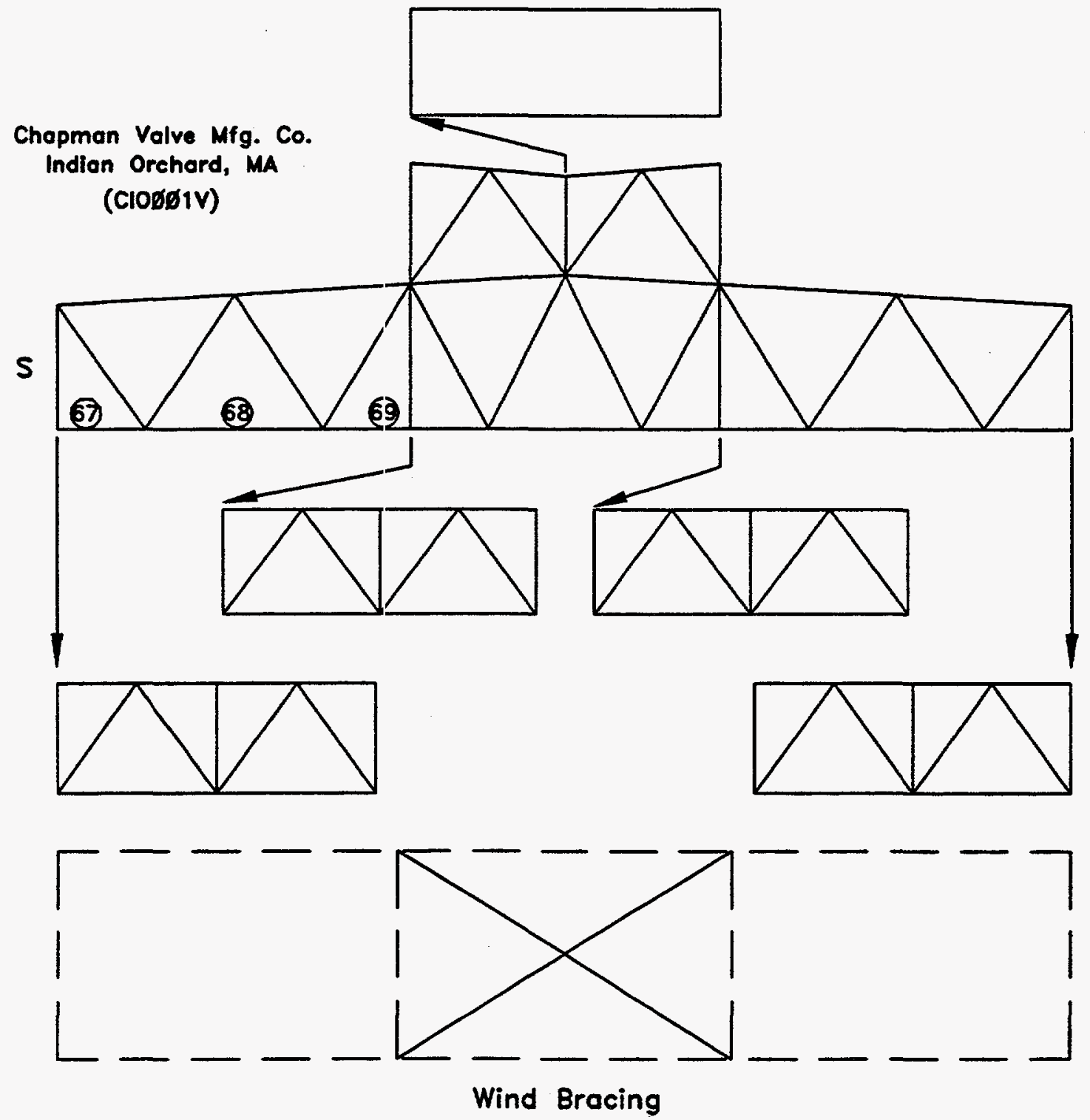

Fig. 9. Locations of directly measured beta-gamma activity levels (dpm/100 $\mathrm{cm}^{2}$ ) and smears collected on Truss $\# 7$ in Building 23 at the site of the former Chapman Valve facility, Indian Orchard, Massachusetts. 


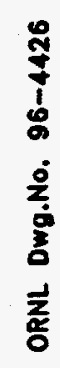

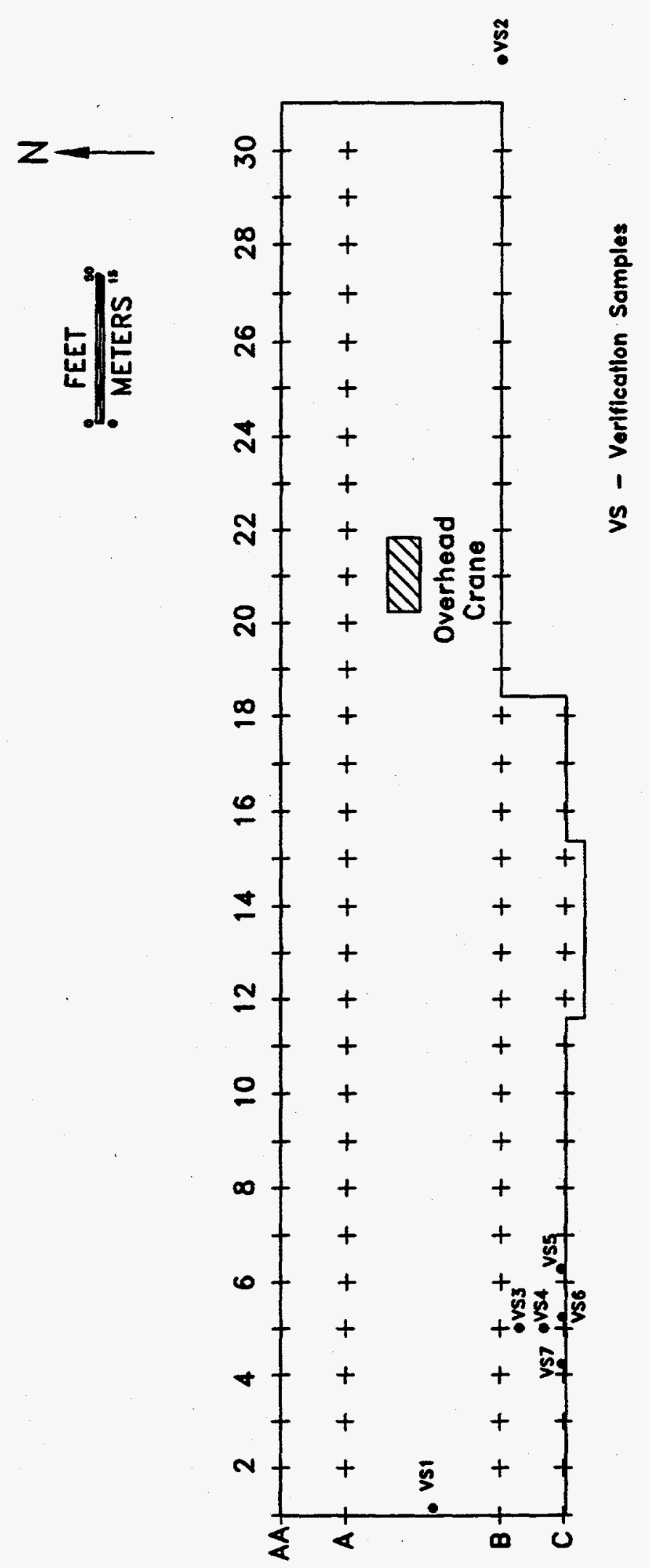

흘

$\frac{0}{3}$

옹
음
동

๕ั

$\stackrel{\circ}{=}$

5

$\stackrel{\circ}{\frac{5}{5}}$

$\stackrel{9}{=}$

ธ

:

है

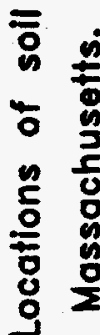

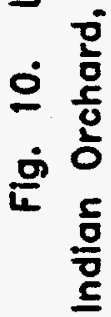


Table 1. Applicable guidelines for protection against radiation (Limits for uncontrolled areas)

Mode of exposure

Gamma radiation

Total residual surface contamination ${ }^{b, c}$

Beta-gamma dose rates

Radionuclide concentrations in soil (generic)

Derived concentrations
Exposure conditions

Indoor gamma radiation level (above background)

2:18U, 235U, U-natural (alpha emitters)

or

Beta-gamma emitters ${ }^{d}$

Maximum

Average

Removable

2:i2Th, Th-natural (alpha emitters)

or

90) $\mathrm{Sr}$ (beta-gamma emitter)

Maximum

Average

Removable

22.6Ra, $230 \mathrm{Th}$, transuranics

Maximum

Average

Removable

Surface dose rate averaged over not more than $1 \mathrm{~m}^{2}$

Mlaximum dose rate in any

$$
00-\mathrm{cm}^{2} \text { area }
$$

Maximum permissible concentration of the following radionuclides in soil above background levels, averaged over a $100-\mathrm{m}^{2}$ area

$$
\begin{aligned}
& 226 \mathrm{Ra} \\
& 232 \mathrm{Th} \\
& \text { 230Th }
\end{aligned}
$$

$1.0 \mathrm{mrad} / \mathrm{h}$

Guideline value

$20 \mu \mathrm{R} / \mathrm{h}^{a}$

$15,000 \mathrm{dpm} / 100 \mathrm{~cm}^{2}$ $5,000 \mathrm{dpm} / 100 \mathrm{~cm}^{2}$ $1,000 \mathrm{dpm} / 100 \mathrm{~cm}^{2}$

$3,000 \mathrm{dpm} / 100 \mathrm{~cm}^{2}$ $1,000 \mathrm{dpm} / 100 \mathrm{~cm}^{2}$ $200 \mathrm{dpm} / 100 \mathrm{~cm}^{2}$

$300 \mathrm{dpm} / 100 \mathrm{~cm}^{2}$ $100 \mathrm{dpm} / 100 \mathrm{~cm}^{2}$ $20 \mathrm{dpm} / 100 \mathrm{~cm}^{2}$

\section{$0.20 \mathrm{mrad} / \mathrm{h}$}

$5 \mathrm{pCi} / \mathrm{g}$ averaged over the first $15 \mathrm{~cm}$ of soil below the surface; 15 $\mathrm{pCi} / \mathrm{g}$ when averaged over $15 \mathrm{~cm}$-thick soil layers $>15 \mathrm{~cm}$ below the surface 
Table 1. (continued)

Mode of exposure

Guideline for non-

homogeneous con-

tamination (used in

addition to the

$100-\mathrm{m}^{2}$ guideline) $f$
Exposure conditions

Applicable to locations with an area $\leq 25 \mathrm{~m}^{2}$, with significantly elevated concentrations of radionuclides ("hot spots")
Guideline value
$G_{A}=G_{i}(100 / A)^{1 / 2}$, where
$G_{A}=$ guideline for"hot spot" of area $(A)$
$G_{i}=$ guideline averaged
over a $100-\mathrm{m}^{2}$ area

${ }^{a}$ The $20 \mu \mathrm{R} / \mathrm{h}$ shall comply with the basic dose limit (100 mrem/yr) when an appropriate-use scenario is considered.

bDOE surface contamination guidelines are consistent with NRC Guidelines for Decontamination at Facilities and Equipment Prior to Release for Unrestricted Use or Termination of Licenses for By-Product, Source, or Special Nuclear Material, May 1987.

cLimits not applicable for the first eight trusses on the west end of the building. Source: Memo, J. W. Wagoner II, Dirctor, Division of Off-Site Programs, Office of Eastern Area Programs, Office of Environmental Restoration, U. S. DOE, to L. K. Price, Director, Former Sites Restoration Division, Oak Ridge Field Office, U.S. DOE, July 27, 1995.

$d$ Beta-gamma emitters (radionuclides with decay modes other than alpha emission or spontaneous fission) except ${ }^{90} \mathrm{Sr},{ }^{228} \mathrm{Ra},{ }^{223} \mathrm{Ra},{ }^{227} \mathrm{Ac},{ }^{133} \mathrm{I},{ }^{129} \mathrm{I},{ }^{126} \mathrm{I}, 125 \mathrm{I}$.

eDOE guidelines for uranium are derived on a site-specific basis. Guidelines of $35-40 \mathrm{pCi} / \mathrm{g}$ have been applied at other FUSRAP sites. Sources: J. L. Marley and R. F. Carrier, Results of the Radiological Survey at 4 Elmhurst Avenue, Colonie, New York (AL219), ORNL/RASA-87/117, Martin Marietta Energy Systems, Inc., Oak Ridge Natl. Lab., February 1988; B. A. Berven et. al., Radiological Survey of the Former Kellex Research Facility, Jersey City, New Jersey, DOE/EV-0005/29, ORNL-5734, Martin Marietta Energy Systems, Inc., Oak Ridge Natl. Lab., February 1982.

fDOE guidelines specify that every reasonable effort shall be made to identify and to remove any source that has a concentration exceeding 30 times the guideline value, irrespective of area (adapted from Revised Guidelines for Residual Radioactive Material at FUSRAP and Remote SFMP Sites, April 1987).

Sources: Adapted from U.S. Department of Energy, Radiation Protection of the Public and the Environment, DOE Order 5400.5, April 1990, and U.S. Department of Energy, Guidelines for Residual Radioactive Material at Formerly Utilized Sites Remedial Action Program and Remote Surplus Facilities Management Program Sites, Rev. 2, March 1987; and U. S. Department of Energy Radiological Control Manual, DOE N 5480.6 (DOE/EH-256T), June 1992. 
Table 2. Background radiation levels and concentrations of selected radionuclides in soil in the Beverly, Massachusetts, area

Type of radiation measurement

Radiation level or radionuclide or sample concentration

Range Average

\begin{tabular}{lcc}
\hline $\begin{array}{l}\text { Gamma exposure rate at } \\
\text { ground surface }(\mu \mathrm{R} / \mathrm{h}){ }^{k i}\end{array}$ & $6-9$ & 7 \\
& & \\
$\begin{array}{l}\text { Concentration of radionuclides } \\
\text { in soil }(\mathrm{pCi} / \mathrm{g})^{a}\end{array}$ & & \\
$226 \mathrm{Ra}$ & & \\
$232 \mathrm{Th}$ & $0.70-1.8$ & 1.1 \\
$238 \mathrm{U}$ & $0.76-1.2$ & 0.97 \\
\end{tabular}

$a$ Values obtained from six locations in the Beverly, Massachusetts, area.

Source: R. D. Foley, M. S. Uziel, Results of the Radiological Survey at the Former Chapman Valve Manufacturing Company, Indian Orchard, Massachusetts (CIOO01), ORNL/RASA.92/1, Martin Marietta Energy Systems, Inc., Oak Ridge Natl. Lab., July 1992. 
Table 3. Direct and transferable beta-gamma and alpha measurements on overhead trusses in Building 23 for the verification of the former Chapman Valve Manufacturing Company facility

\begin{tabular}{|c|c|c|c|}
\hline \multirow[b]{2}{*}{$\begin{array}{l}\text { Location } \\
\text { No.a }\end{array}$} & \multicolumn{2}{|c|}{$\begin{array}{l}\text { Directly measured } \\
\text { activity }\end{array}$} & \multirow{2}{*}{$\begin{array}{c}\begin{array}{c}\text { Removable } \\
\text { activity }\end{array} \\
\text { Smear No. }{ }^{b}\end{array}$} \\
\hline & $\begin{array}{r}\text { Beta-gamma } \\
\text { (dpm/100 }\end{array}$ & $\begin{array}{l}\text { Alpha } \\
\left.\mathbf{m}^{2}\right)\end{array}$ & \\
\hline & \multicolumn{2}{|c|}{ Truss \# 1} & \\
\hline 1 & 24,000 & $c$ & VT1 \\
\hline 2 & 5,000 & 330 & VT2 \\
\hline 3 & 13,500 & c & VT3 \\
\hline 4 & 6,000 & $c$ & VT4 \\
\hline 5 & 1,800 & 430 & VT5 \\
\hline 6 & 8,400 & $c$ & VT6 \\
\hline 7 & 3,000 & 112 & VT7 \\
\hline 8 & 1,800 & $c$ & VT8 \\
\hline \multirow[t]{2}{*}{9} & 6,000 & c & VT9 \\
\hline & \multicolumn{2}{|c|}{ Truss \# 2} & \\
\hline 10 & 21,000 & 30 & VT10 \\
\hline 11 & 1,800 & $c$ & VT11 \\
\hline 12 & 2,700 & $c$ & VT12 \\
\hline 13 & 24,000 & $10 d$ & VT13 \\
\hline 14 & 9,500 & $c$ & VT14 \\
\hline 15 & 18,000 & c & $e$ \\
\hline 16 & 27,000 & c & $e$ \\
\hline 17 & 4,500 & $c$ & $e$ \\
\hline 18 & 24,000 & $10^{d}$ & VT18 \\
\hline 19 & 21,000 & c & e \\
\hline 20 & 7,500 & c & $e$ \\
\hline 21 & 24,000 & $c$ & $e$ \\
\hline 22 & 15,000 & $c$ & $e$ \\
\hline 23 & 18,000 & 780 & VT23 \\
\hline 24 & 10,500 & $c$ & VT24 \\
\hline 70 & 15,000 & $c$ & VT70 \\
\hline 71 & 24,500 & c & $e$ \\
\hline 72 & 10,500 & $c$ & $e$ \\
\hline \multirow[t]{2}{*}{78} & 6,600 & c & $e$ \\
\hline & \multicolumn{2}{|c|}{ Truss \# 3} & \\
\hline 25 & 6,600 & $c$ & VT25 \\
\hline 26 & 4,800 & $c$ & $e$ \\
\hline
\end{tabular}


Table 3 (continued)

\begin{tabular}{|c|c|c|c|}
\hline \multirow{3}{*}{$\begin{array}{c}\text { Location } \\
\text { No.a }\end{array}$} & \multicolumn{2}{|c|}{$\begin{array}{l}\text { Directly measured } \\
\text { activity }\end{array}$} & \multirow{3}{*}{$\begin{array}{c}\begin{array}{c}\text { Removable } \\
\text { activity }\end{array} \\
\text { Smear No.b }\end{array}$} \\
\hline & Beta-gamma & Alpha & \\
\hline & \multicolumn{2}{|c|}{$\left(\mathrm{dpm} / 1.00 \mathrm{~cm}^{2}\right)$} & \\
\hline & \multicolumn{3}{|c|}{ Truss \# 3 (cont) } \\
\hline $\begin{array}{l}27 \\
28\end{array}$ & $\begin{array}{l}12,000 \\
60,000\end{array}$ & $\begin{array}{l}c \\
150\end{array}$ & $\begin{array}{l}e \\
\text { VT2 } 28\end{array}$ \\
\hline 29 & 6,600 & $c$ & $e$ \\
\hline 30 & 17,000 & c & $e$ \\
\hline 31 & 4,500 & $c$ & $e$ \\
\hline 32 & 3,000 & $c$ & VT32 \\
\hline 33 & 2,400 & $c$ & $e$ \\
\hline 34 & 30,000 & $c$ & $e$ \\
\hline 35underside & 5,500 & $c$ & $e$ \\
\hline 36underside & 2,500 & $c$ & $e$ \\
\hline 38underside & $O_{d}^{d}$ & $c$ & $e$ \\
\hline 39 & 24,000 & $c$ & $e$ \\
\hline 40verticle truss & 870 & $c$ & $e$ \\
\hline 75 & 4,500 & $c$ & $e$ \\
\hline $\begin{array}{l}76 \\
77\end{array}$ & $\begin{array}{c}9,000 \\
21,000\end{array}$ & $c$ & $e$ \\
\hline 80 & 600 & $c$ & $e$ \\
\hline \multirow[t]{2}{*}{81} & 1,350 & $c$ & $e$ \\
\hline & \multicolumn{2}{|c|}{ Truss \# 4} & \\
\hline 41 & 25,000 & $c$ & $e$ \\
\hline 42 & 7,500 & $c$ & e \\
\hline 43 & 1,500 & 160 & $e$ \\
\hline 44underside & $60 d$ & $c$ & $e$ \\
\hline 45 & 900 & $c$ & $e$ \\
\hline 46 & 4,200 & $c$ & VT46 \\
\hline 47 & 13,000 & $c$ & $e$ \\
\hline 48 & 13,000 & $c$ & $e$ \\
\hline 49 & 2,400 & $c$ & $e$ \\
\hline \multirow[t]{2}{*}{50} & 3,000 & $c$ & $e$ \\
\hline & \multicolumn{2}{|c|}{ Truss \# 5} & \\
\hline 51 & 600 & $c$ & $e$ \\
\hline 52 & 3,600 & $c$ & $e$ \\
\hline 53 & 27,0013 & $c$ & $e$ \\
\hline 54underside & od & $c$ & $e$ \\
\hline 55 & 9,000 & $c$ & $e$ \\
\hline 56 & 2,700 & $c$ & $e$ \\
\hline 57 & 900 & $c$ & $e$ \\
\hline
\end{tabular}


Table 3 (continued)

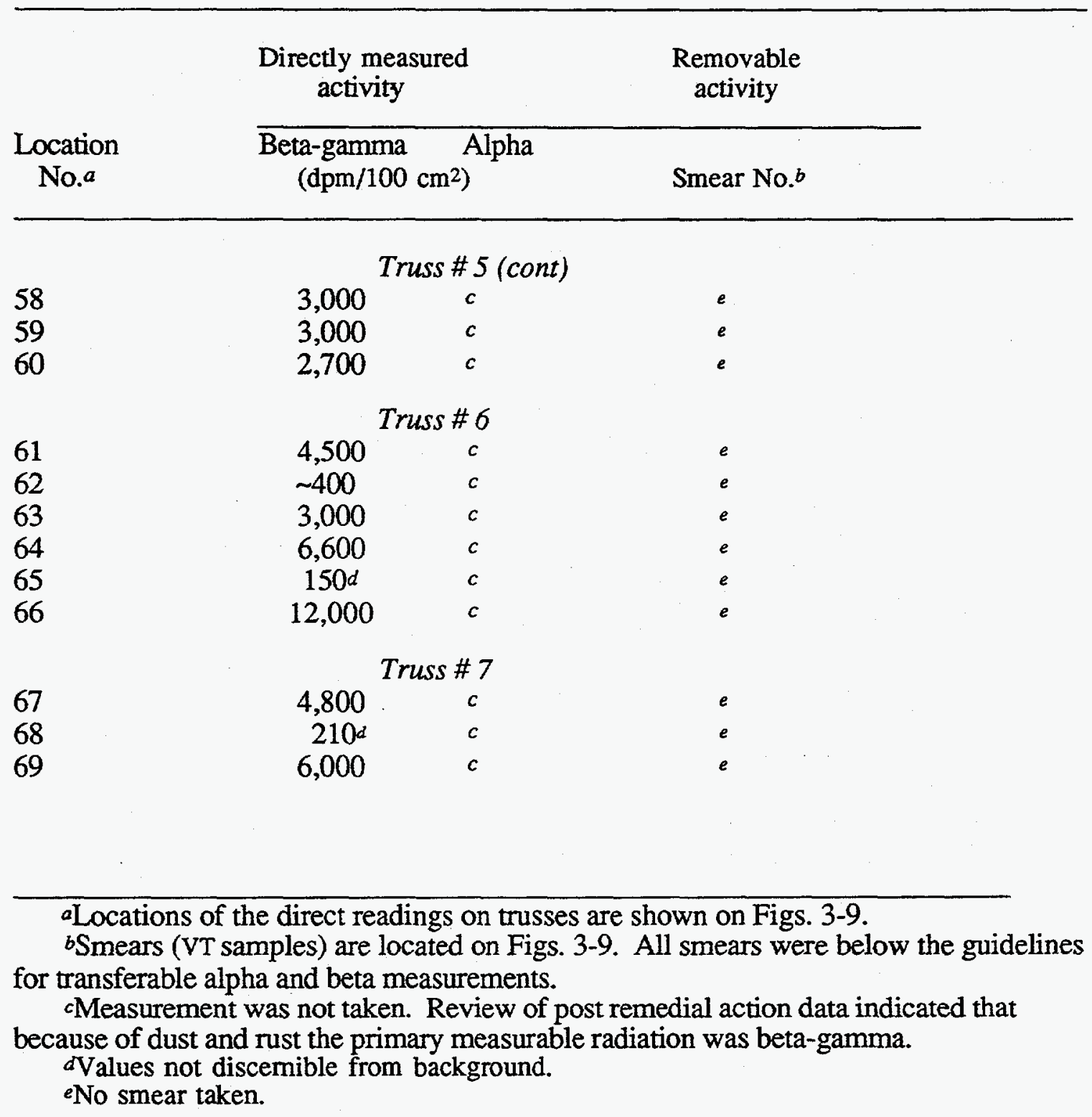


Table 4. Concentrations of radionuclides in soil at the former Chapman Valve Manufacturing Company, Indian Orchard, Massachusetts (CIO001V)

\begin{tabular}{|c|c|c|c|c|c|}
\hline \multirow{2}{*}{$\begin{array}{l}\text { Sample } \\
\text { number }\end{array}$} & \multirow{2}{*}{$\begin{array}{l}\text { Depth } \\
\text { (cm) }\end{array}$} & \multicolumn{4}{|c|}{ Radionuclide concentration $(\mathrm{pCi} / \mathrm{g}) b$} \\
\hline & & $226 \mathrm{Ra}$ & $232 \mathrm{Th}$ & $238 \mathrm{U}$ & $235 \mathrm{U}$ \\
\hline
\end{tabular}

Systematic soil samplesc

$\begin{array}{llllll}\text { VS1 } & 0-15 & 0.47 \pm 0.1 & 0.43 \pm 0.08 & 14 \pm 1 & 0.46 \pm 0.07 \\ \text { VS2 } & 0-15 & 0.56 \pm 0.1 & 0.34 \pm 0.07 & 0.71 \pm 0.3 & 0.09 \pm 0.04 \\ \text { VS3 } & 0-15 & 0.65 \pm 0.2 & 0.31 \pm 0.1 & 0.82 \pm 0.3 & <0.10 \\ \text { VS4 } & 0-8 & 0.57 \pm 0.1 & 0.36 \pm 0.07 & 1.1 \pm 0.4 & <0.08 \\ \text { VS5 } & 0-15 & 0.50 \pm 0.2 & 0.37 \pm 0.2 & 0.98 \pm 0.3 & 0.11 \pm 0.05 \\ \text { VS6 } & 0-15 & 0.43 \pm 0.1 & 0.33 \pm 0.1 & 0.90 \pm 0.3 & <0.05 \\ \text { VS7 } & 0-15 & 0.63 \pm 0.1 & 0.27 \pm 0.06 & 0.87 \pm 0.3 & 0.08 \pm 0.03\end{array}$

$a$ Locations of soil samples are shown on Fig. 10.

$b$ Indicated counting error is at the $95 \%$ confidence level $( \pm 2 \sigma)$.

cSystematic samples are taken at locations irrespective of gamma exposure rates. 
ORNL/RASA-95/17

\section{INTERNAL DISTRIBUTION}

\author{
1. K. J. Brown \\ 2. R. D. Foley \\ 3-4. C. A. Johnson \\ 5. M. E. Murray \\ 6. P. T. Owen \\ 7-9. R. E. Rodriguez
}

\author{
10-15. MAD Records Center \\ 16. R. E. Swaja \\ 17. M. S. Uziel \\ 18. J. K. Williams \\ 19. Central Research Library \\ 20. Laboratory Records-RC \\ 21. ORNL Technical Library, Y-12
}

\section{EXTERNAL DISTRIBUTION}

22. W. L. Beck, Oak Ridge Associated Universities, E/ESD, 1299 Bethal Valley Rd., Oak Ridge, TN 37831

23. J. D. Kopotic, Former Sites Restoration Division, Oak Ridge Operations Office, U. S. Department of Energy, P1O. Box 2001

24. James J. Fiore, Director, Office of Eastern Area Programs, Office of Environmental Restoration, EM-24, U.S. Department of Energy, 19901 Germantown Rd., Germantown, MD 20874-1290

25. Albert Johnson, Program Manager, Formerly Utilized Sites Remedial Action Program, EM-421, U.S. Department of Energy, Cloverleaf Building, 19901 Germantown Rd, Germantown, MD 20874-1290

26. FUSRAP Document Center, Science Applications International Corporation, P.O. Box 2501, 301 Laboratory Road, Oak Ridge, TN 37831

27. S. K Oldham, Former Sites Restoration Division, Oak Ridge Field Office, U.S. Department of Energy, P.O. Box 2001, Oak Ridge, TN 37831-8723

28. L. K. Price, Director, Former Sites Restoration Division, Oak Ridge Field Office, U.S. Department of Energy, P.O. Box 2001, Oak Ridge, TN 37831-8723

29. George Bierman, Booz-Allen \& Hamilton, Inc., 12850 Middlebrook Road, Suite 210, Germantown, MD 20874

30. A. G. Toddings, FUSRAP Project Administrator, Bechtel National, Inc., FUSRAP Department, Oak Ridge Corporate Center, 151 Lafayette Drive, P.O. Box 350, Oak Ridge, TN 37831-0350

31-35. W. Alexander Williams, Designation and Certification Manager, Division of OffSite Programs, Office of Eastern Area Programs, Office of Environmental Restoration, EM-421, U.S. Department of Energy, 19901 Germantown Rd., Germantown, MD 20874-1290

36-37. Office of Scientific and Technical Information, U.S. Department of Energy, P.O. Box 62, Oak Ridge, TN 37831 